Praia de Botafogo, $190-14^{\circ}$ andar - Botafogo 22253-900 - Rio de Janeiro - Rio de Janeiro - Brasil E-mail: thiagokrause@gmail.com

\section{DE HOMENS DA GOVERNANÇA À PRIMEIRA NOBREZA: VOCABULÁRIO SOCIAL E TRANSFORMAÇÕES ESTAMENTAIS NA BAHIA SEISCENTISTA*}

\author{
Thiago Nascimento Krause*
}

Universidade Federal do Rio de Janeiro

\title{
Resumo
}

Ao longo do século XVII, a elite política de Salvador, capital do Estado do Brasil, apropriou-se de um vocabulário social tradicional no reino, passando a se identificar como uma nobreza local e a ser reconhecida como tal. Tal processo deu-se a partir dos embates e contatos políticos com a Coroa portuguesa e seus representantes no ultramar, especialmente a partir da Restauração portuguesa de 1640.

\section{Palavras-chave}

Nobreza - hierarquização social - política.

\footnotetext{
* Agradeço ao CNPq pelo financiamento da pesquisa; a Evaldo Cabral de Mello por suas sugestões, essenciais para dar a esse texto sua forma final; a Mariana Guglielmo, pelas longas discussões; a Gustavo Bernardo, pela cuidadosa revisão; a Carlos Gabriel Guimarães, Guilherme Pereira das Neves e Antônio Carlos Jucá, por seus comentários em eventos; a João Fragoso, Nuno Monteiro, Ronald Raminelli, Roberto Guedes, Rodrigo Ricupero, Christopher Ebert, Renato Silva e aos pareceristas anônimos por suas argutas críticas.

${ }^{* *} \mathrm{O}$ autor é bolsista de doutorado do CNPq, professor de História Moderna na Escola Superior de Ciências Sociais da Fundação Getúlio Vargas (FGV)-Rio de Janeiro, Centro de Pesquisa e Documentação de História Contemporânea do Brasil (Cpdoc).
} 
Contact $22253-900$ - Rio de E-mail: thiagokrause@gmail.com

\section{FROM MEN OF \\ GOVERNANCE TO \\ FIRST NOBILITY:}

SOCIAL VOCABULARY

AND THE REMAKING

OF ELITE STATUS IN

SEVENTEENTH-CENTURY

BAHIA

Thiago Nascimento Krause

Universidade Federal do Rio de Janeiro

\begin{abstract}
This article shows how, throughout the seventeenth-century, the political elite of Salvador, capital of the State of Brazil, claimed the social classification common in Portugal as their own, thus representing itself as a local nobility and being recognized as such. This process took place because of the confrontations and negotiations with the Portuguese Crown and its representatives, markedly since the Portuguese Restoration of 1640.
\end{abstract}

\title{
Keywords
}

Nobility - social hierarchies - politics. 


\section{Introdução}

Em 1986, Evaldo Cabral de Mello iniciou um debate que teria grande influência na historiografia sobre o período colonial. Através de um cuidadoso estudo das crônicas do período holandês e do conflito entre a elite açucareira e os negociantes recifenses, o historiador pernambucano examinou as transformações na estratificação social em Pernambuco de meados do século XVII até o início do XVIII. Demonstrou, assim, como, na "conflitiva segunda metade de Seiscentos, a açucarocracia pernambucana passa a autodesignarse pela mesma expressão consagrada no reino para denominar as oligarquias municipais": nobreza da terra. Esse grupo era composto pelas mais ricas famílias canavieiras que lutaram contra os flamengos ou exerceram os ofícios camarários, e se consolidou primeiro a partir da experiência de dominação neerlandesa e da mobilização para sua expulsão e, posteriormente, durante o conflito com os mascates. ${ }^{1}$

Em outra obra, o autor explicita as bases sociológicas de sua reflexão, de matriz weberiana, afirmando que "a utilização simultânea dos conceitos de ordem e de classe permite compreender melhor, por exemplo, a metamorfose da açucarocracia (situação de mercado) em nobreza da terra (situação de statu)". Assim, a elite pernambucana possuía características constituintes de uma classe, "inclusive o seu lugar específico no processo de produção", mas sua identidade e a imagem que dela tinham os outros estratos sociais baseavam-se numa construção estamental: “a nobreza da terra, cuja mentalidade, transplante metropolitano adaptado à sua experiência local, é tão indispensável conhecer, a fim de compreendê-la na sua atuação histórica, como sua condição de classe". ${ }^{2}$

O pioneirismo do historiador pernambucano esteve, dentre outros aspectos, em sua preocupação de recuperar os conceitos da época e seus efeitos na sociedade e política luso-brasileira, assim como o diálogo com a historiografia portuguesa. Posteriormente, tais características se disseminaram entre os historiadores brasileiros. Na perspectiva social e econômica, João Fragoso estudou a formação e as práticas políticas da "nobreza principal da terra" do Rio de Janeiro, classificação retirada de um emblemático documento de 1732.

\footnotetext{
1 MELLO, Evaldo Cabral de. Rubro veio: o imaginário da Restauração pernambucana. $3^{\text {a }}$ ed. rev. São Paulo: Alameda, 2008, p. 155-80, citação à p. 155.

2 MELLO, Evaldo Cabral de. A fronda dos mazombos: nobres contra mascates, Pernambuco, 1666-1715. $2^{\text {a }}$ ed. rev. São Paulo: 34, 2003, p. 18.
} 
rev. hist. (São Paulo), n. 170, p. 201-232, jan.-jun., 2014 http://dx.doi.org/10.11606/issn.2316-9141.v0i170p201-232
Thiago Nascimento Krause

De homens da governança à primeira nobreza: vocabulário social e transformações estamentais na Bahia seiscentista

Por não ser sua "intenção fazer uma arqueologia de tal expressão", o historiador carioca utilizou o termo indistintamente para se referir à elite agrária fluminense entre finais do século XVI e meados do XVIII, construída a partir da conquista da terra contra indígenas e franceses e da ocupação dos cargos no poder local. Mesmo assim, o autor demonstrou que expressões como "mulher nobre das principais da terra" (1621), "das pessoas mais nobres da dita cidade e governança dela" (1628), "os homens bons e pessoas nobres do governo da República" (1646) eram utilizadas desde a primeira metade do século XVII. ${ }^{3}$ Entretanto, a utilização do conceito tem sofrido críticas, sendo a mais influente a de Laura de Mello e Souza que enfatizou o caráter distintivo da escravidão para afirmar que

o fato de membros das elites coloniais se autodenominarem "nobreza da terra" não autoriza, creio, os historiadores a tomarem o que é construção ideológica por conceito sociológico. Da mesma forma, o fato de existirem aristocracias regionais - a menos equívoca, sendo, por certo, a da velha região açucareira do Nordeste, nomeadamente em Pernambuco - não permite extrapolar para a constatação de que a sociedade luso-americana dos séculos XVI, XVII e XVIII conheceu, na nobreza da terra, uma formação social análoga à do Ancien Régime europeu. ${ }^{4}$

A Bahia, porém, tem permanecido de fora desse debate, apesar da importância econômica e política da capitania, "cabeça do Estado do Brasil" até 1763 e maior produtora de açúcar após a invasão neerlandesa de Pernambuco em 1630 - isto é, a mais rica região da América portuguesa até a descoberta do ouro no interior da região centro-sul.

Meu objetivo é, portanto, contribuir para o debate através da análise do vocabulário da estratificação social ${ }^{5}$ na Bahia do século XVII, período que acredito ter sido decisivo na formação das nobrezas locais americanas, embora menos estudado do que os Setecentos. Para tal, utilizarei intensivamente as Atas da Câmara completas para o período posterior à expulsão dos neerlandeses, iniciando em agosto de 1625. Para o Senado soteropolita-

\footnotetext{
3 FRAGOSO, João. À espera das frotas: micro-história tapuia e a nobreza principal da terra (Rio de Janeiro, c. 1600 - c. 1750). Tese de titular em Teoria da História, Departamento de História, Universidade Federal do Rio de Janeiro, 2005 p. 30 e 32.

4 SOUZA, Laura de Mello e. O sol e a sombra: política e administração na América portuguesa do século XVIII. São Paulo: Companhia das Letras, 2006, p. 179-80, nota 56; ver também p. 41-77.

${ }^{5}$ Por sua importância, cf. MONTEIRO, Nuno Gonçalo. Poder senhorial, estatuto nobiliárquico e aristocracia. In: MATTOSO, José (dir.) e HESPANHA, António Manuel. História de Portugal, vol. IV: O Antigo Regime (1620-1807). $2^{\mathrm{a}}$ ed. Lisboa: Estampa, 1998, p. 297-301.
} 
no também foi possível identificar o maior corpus epistolar dentre todas as municipalidades do Brasil seiscentista, somando as registradas nos livros do Senado àquelas depositadas no Arquivo Histórico Ultramarino (AHU), num total de mais de 500 missivas. Através de uma análise sistemática do vocabulário social nessa documentação, investigarei a "construção ideológica" de uma nobreza brasílica e sua "identidade social", capaz de influenciar seu comportamento político e econômico. ${ }^{6}$ Meu estudo parte do princípio, enunciado pelo hispanista I. A. A. Thompson de que "a elaboração de uma nova terminologia, ou de um novo uso da linguagem, não é algo casual ou carente de significado. A linguagem aporta significado; um novo uso linguístico assinala um novo significado ou lhe confere um novo sentido". No Antigo Regime, o vocabulário social implicava também efeitos facilmente discerníveis nas relações sociais, nomeadamente na seara dos privilégios estamentais juridicamente definidos, fosse pela Coroa ou pelos costumes locais. Dessa maneira, esses também precisam ser investigados, já que se constituem em uma das definições mais clássicas da nobreza.

Essa abordagem oferece, porém, obstáculos metodológicos, exigindo “a análise textual de uma documentação homogênea de larga duração, contínua (...) e relevante; quer dizer, que fosse a expressão corrente de um discurso político ordinário". 7 As opções não são muitas, mas, dentre as poucas fontes adequadas, é possível mencionar as atas das municipalidades, os mais relevantes depósitos da memória administrativa local e das discussões políticas cotidianas.

\section{Antecedentes: principais e cidadãos?}

Certamente, o vocabulário da estratificação não surgiu ex nihilo em 1625, tendo sido resultado de mutações no século que o precedeu. A limitação das fontes impede, porém, uma análise mais sistemática, de modo que serei obrigado a realizar apenas alguns apontamentos a partir de dados esparsos.

\footnotetext{
6 BÜSCHGES, Christian e SCHRÖTER, Bernd. Las capas altas urbanas en la América hispânica colonial In: Idem (eds.). Benméritos, aristócratas y empresários: identidades y estructuras sociales de las capas altas urbanas en América hispânica. Madri/Frankfurt: Iberoamericana/Vervuert, 1999, p. 308-14. Os autores notam como, "na maioria das maiores, mais importantes e antigas cidades [da América espanhola], o estrato social mais elevado adquiriu no decurso do tempo uma identidade nobiliárquica" (p. 312, tradução minha).

7 THOMPSON, Irving. La monarquía de España: La invención de um concepto. In: ÁLVAREZ, Francisco Guillamón; RODRÍGUEZ, Júlio Muñoz e ARCE, Domingo Centenero (eds.). Entre Clío y Cassandra: Poder y sociedad en la monarquía hispánica durante la Edad Moderna. Murcia: Universidade de Murcia, 2005, p. 33 e 35 (tradução minha).
} 
Ao se referir aos moradores mais destacados da Bahia em finais dos Quinhentos, Gabriel Soares de Sousa utiliza o vocábulo "principal", como em "os principais e mais ricos moradores". Entretanto, que este termo não tinha um significado unívoco pode ser percebido pelo fato de ele ser utilizado inclusive para nomear as lideranças indígenas. ${ }^{8}$ Não há nenhuma tentativa de caracterizar a elite em formação como nobreza, diferentemente de Pero de Magalhães Gandavo que, em 1576, afirmou que “a principal [povoação] onde residem os do governo da terra e mais da gente nobre, é a Cidade de Salvador", relegando o termo principal apenas para os indígenas. ${ }^{9}$ É de se notar, porém, que Gandavo, embora possivelmente tenha passado alguns anos na Bahia, não havia feito nela sua vida como Soares de Sousa, e certamente estava mais distante do discurso e da experiência da elite local em formação.

Ao registrar a fala dos depoentes, a documentação da primeira visitação do Santo Ofício permite uma aproximação um pouco mais precisa do vocabulário social na última década do século XVI. Em 22 de agosto de 1591, João Serrão confessou ser cristão-novo, apesar de em público afirmar sua limpeza de sangue, "por ele estar casado nesta cidade com uma mulher cristã velha de gente nobre, limpa e abastada, e ele ser tido de todos por cristão velho e ser cidadão que já foi almotacé desta cidade, havido em boa conta e de honrado". Mesmo assim, a expressão "gente nobre" ainda não parece ser de uso corrente, já que aparece apenas nesse documento. ${ }^{10}$ Por último, já no início de nosso recorte cronológico, frei Vicente do Salvador, em sua História do Brazil, refere-se a membros da elite baiana desde as primeiras décadas como "cidadãos", raramente qualificando alguém como nobre - embora o tenha feito com Gabriel Soares de Sousa.

O termo "cidadão", significando aquele que participa da política municipal, parece ter nesse momento um caráter individual, não representando ainda uma coletividade. Mesmo a "gente nobre" tem ainda um significado vago, referindo-se antes a alguns indivíduos seletos do que a uma coletividade definida. Uma postura da Câmara sem data, mas produzida entre 1604 e 1607, fala em "pessoas da governança"11 enquanto carta ao governador

\footnotetext{
8 SOUSA, Gabriel Soares de. Tratado descritivo do Brasil em 1587. São Paulo: Hedra, 2010, p. 63, 65, 137 e 139.

9 GANDAVO, Pero de Magalhães. Tratado da terra do Brasil \& História da província Santa Cruz a que vulgarmente chamamos Brasil, 1576. Recife: Massangana, 1995, p. 60.

${ }^{10}$ VAINFAS, Ronaldo (org.). Confissões da Bahia. $2^{\mathrm{a}}$ ed. São Paulo: Companhia das Letras, 1997, confissão n. 20; cf. também as confissões 32 e 44.

${ }^{11}$ Documentos históricos do Arquivo Municipal: Atas da Câmara. Salvador: Prefeitura Municipal, 11 vols. (1625-1775), 1949-2011 (doravante AC), vol. I, p. 101.
} 
geral Gaspar de Sousa em 1614 utiliza o termo ambíguo "principais da terra", mas se refere também à "gente tão nobre" de Salvador e aos "mais nobres e honrados mancebos desta terra".12 A julgar pelas denunciações e confissões do Santo Ofício de 1618, os membros da elite identificavam-se e eram identificados como senhores de engenho, quando muito como juízes ordinários e vereadores - e, em alguns raros casos, fidalgos da Casa Real. ${ }^{13}$

Mesmo assim, é apenas a partir de 1625 que se torna possível arriscar interpretações baseadas em uma documentação mais consistente. Entretanto, o caminho a ser seguido pode ser apontado por outras regiões do Atlântico português, ocupadas há mais tempo: nos Açores, por exemplo, a partir da relação com o donatário e, depois, com a Coroa, consolidou-se, na transição do século XV para o XVI, uma elite terratenente, endogâmica e senhora de um pequeno número de cativos, produzindo-se então, a partir de finais do XVI, um discurso nobiliárquico a legitimar a posição desse grupo. ${ }^{14}$

\section{Homens bons, homens da governança}

Já em 3 de agosto de 1625, na primeira reunião da Câmara após a expulsão dos neerlandeses, os camaristas convocaram "os homens bons que andam na governança" para eleger um juiz ordinário, em razão do falecimento do anterior. ${ }^{15}$ Esta era, porém, apenas uma das muitas formas utilizadas: "homens da governança" e outras variações aparecem 33 vezes entre 1625 e 1640. ${ }^{16}$ Em 1626, porém, há referências aos "homens nobres, e da governança da cidade", reaparecendo em 1631 como os "homens nobres que costumam andar na governança da terra", "pessoas nobres, e da governança” ou, ainda,

\footnotetext{
${ }^{12}$ Oficiais da Câmara de Salvador. Carta ao governador geral Gaspar de Sousa. 13 de março de 1614. Arquivo Histórico Ultramarino (doravante AHU), Bahia, Luiza da Fonseca (LF), cx. 1, doc. 58.

${ }^{13}$ Livro das denunciações que se fizerão na visitação do Santo Offício á cidade do Salvador da Bahia de Todos os Santos do Estado do Brasil, no anno de 1618. Inquiridor e visitador o licenciado Marcos Teixeira. Anais da Biblioteca Nacional. Rio de Janeiro: Biblioteca Nacional, 1936, vol. 49, p. 75-198 e SIQUEIRA, Sônia (ed.). Confissões da Bahia (1618-1620). 2a ed. João Pessoa: Ideia, 2011.

${ }^{14}$ Cf. GREGÓRIO, Rute Dias. Configurações de uma pequena nobreza e seu patrimônio, Açores, séculos XV e XVI, 2010, Disponível em: https://repositorio.uac.pt/handle/10400.3/1084. Acesso em: 19/03/2013, e RODRIGUES, José Damião. Sociedade e administração nos Açores (séculos XV-XVIII): O caso de Santa Maria. Arquipélago-História, Ponta Delgada, $2^{\mathrm{a}}$ série, vol. I, $\mathrm{n}^{\mathrm{o}} 2$ : Estudos insulares, 1995, p. 33-63.

${ }^{15} \mathrm{AC}$, vol. I, p. 3.

${ }^{16}$ AC, vol. I, p. 31-2, 76-7, 83, 179-80, 182, 187-8, 211, 236-7, 267-8, 279-80, 281-3, 299, 306, 312, 332 , 341, 346-7, 353-4, 358-9, 369-75, 401-2, 405-6 e 414-8. Cf. também Oficiais da Câmara de Salvador. Carta ao rei Felipe III de Portugal. 16 de maio de 1626. AHU, Bahia, LF, cx. 3, docs. 423-4.
} 
somente "homens nobres". No total, são nove referências do tipo nesses 15 anos, ${ }^{17}$ similares à expressão consagrada para se referir às oligarquias municipais reinóis: "gente nobre da governança".18

\section{Gráfico 1}

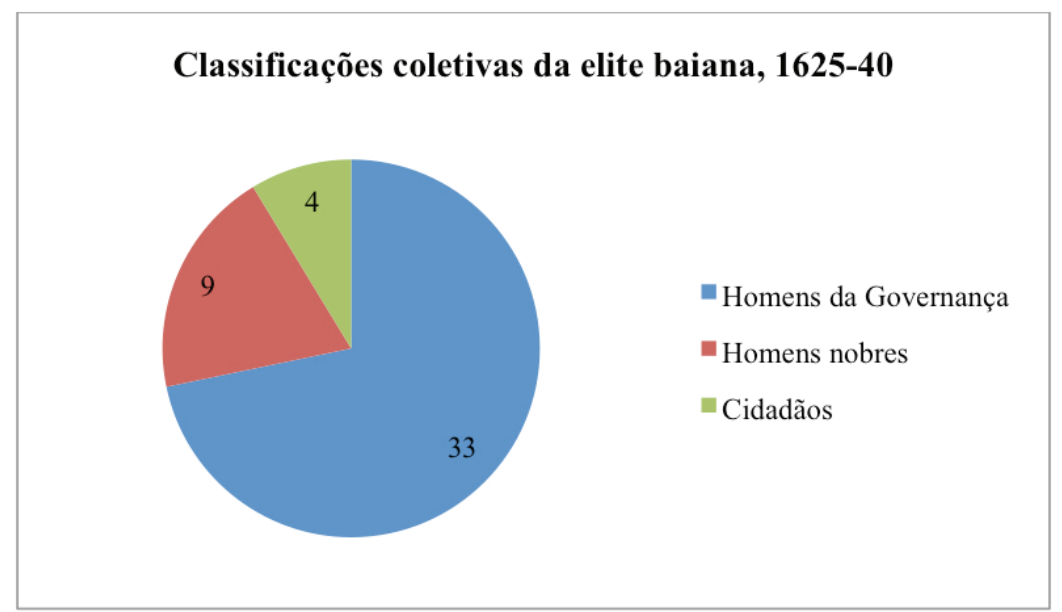

Fontes: AC, vol. I; AHU, Bahia, LF, cx. 3, docs. 423-4.

Como é improvável que cada uma dessas mínimas variações representasse um grupo distinto, e quase todas aparecem quando os camaristas decidem abrir o espaço decisório para outros que não estavam ocupando cargos no Senado no momento (embora muitas vezes o tenham feito antes ou depois), nesses 46 casos, a referência parece ser sempre ao mesmo grupo: a elite local. A terminologia que a caracterizava era, porém, extremamente variável, mas de modo geral o que predomina é a referência à atuação política na "governança" municipal, presente em 44 das 46 referências. Ser nobre é uma característica vacilante do grupo que raramente lhe é atribuída. Não há ainda uma fórmula estabelecida, e o mesmo escrivão e até os mesmos camaristas podiam se referir à elite política de forma distinta em um curto intervalo de tempo. ${ }^{19}$

\footnotetext{
${ }^{17}$ AC, vol. I, p. 37-8, 146-7, 188-90, 202-4, 219-20, 240-1, 253-4.

${ }^{18}$ Cf. MAGALHÃES, Joaquim Romero. Os nobres da governança das terras. In: MONTEIRO, Nuno Gonçalo; CARDIM, Pedro e CUNHA, Mafalda Soares da (coords.). Optima Pars: elites ibero-americanas do Antigo Regime. Lisboa: Imprensa de Ciências Sociais, 2005, p. 65-71.

${ }^{19}$ Cf., por exemplo, AC, vol. I, p. 136-7 e 179-80.
} 


\section{Os três estados da República}

Com a chegada do marquês de Montalvão, porém, surge um novo e interessante modelo classificatório. Em portaria de 12 de setembro de 1640, o vice-rei ordena que "se ajuntem e chamem as pessoas que lhes parecer de maior zelo, de mais experiência e de melhor juízo, assim religiosos como de todos os estados" para decidir sobre os meios para sustentar a infantaria, sendo prontamente obedecido pela Câmara. ${ }^{20}$ Apesar de Montalvão não explicitar quais estados seriam estes, a referência aos religiosos deixa claro que a inspiração aqui é a divisão tripartida medieval entre clero, nobreza e povo, de acordo com o modelo das Cortes portuguesas. Embora nelas as cidades representassem "o povo", assim como em Castela, seus procuradores eram membros de e eleitos pelas oligarquias locais. ${ }^{21} \mathrm{~A}$ existência dessas reuniões tripartidas no âmbito municipal era bem conhecida no reino e em Goa nesse século. ${ }^{22}$

Nos dois lados do Atlântico, as demandas fiscais do centro político e seus representantes constituíam a principal razão para essas reuniões. Mesmo assim, é de se perceber que a divisão tripartida ainda estava pouco consolidada em Salvador, pois d. João IV é aclamado em Salvador pelo "clero, povo e mais gente" em 15 de fevereiro de $1641 .{ }^{23}$ É possível que a soma da iniciativa de Montalvão com a Restauração portuguesa, que imediatamente convocou as Cortes, tenha estimulado a definição da elite baiana de acordo com os modelos reinóis, pois, já em meados de 1641, os camaristas se referem aos "nobres da cidade" e, logo depois, à "nobreza da cidade", ${ }^{24}$ utilizando pela primeira vez um substantivo coletivo que explicita o quanto esse status não é individual, mas resultado de uma "situação estamental" comum.

\footnotetext{
${ }^{20}$ AC, vol. I, p. 451-6.

${ }^{21}$ Cf. CARDIM, Pedro. Entre o centro e as periferias. A assembleia de Cortes e a dinâmica política da época moderna In: CUNHA, Mafalda Soares da e FONSECA, Teresa (orgs.). Os municípios no Portugal moderno: dos forais manuelinos às reformas liberais. Lisboa: Colibri, 2005, p. 167-242.

${ }^{22}$ SILVA, Francisco Ribeiro da. O Porto e o seu termo (1580-1640): os homens, as instituições e o poder. Porto: Arquivo Histórico/Câmara Municipal, 1988, vol. I, p. 234 e PISSURLENCAR, Panduronga. Assentos do Conselho de Estado. Bastorá/Goa: Tipografia Rangel, 1956-7, vol. 4 (1659-95), p. 126, 194 e 351 e vol. 5 (1696-1750), p. 58-97.

${ }^{23}$ AC, vol. II, p. 9-10.

${ }^{24}$ AC, vol. II, p. 28-30 e 35-9.
} 


\section{Gráfico 2}

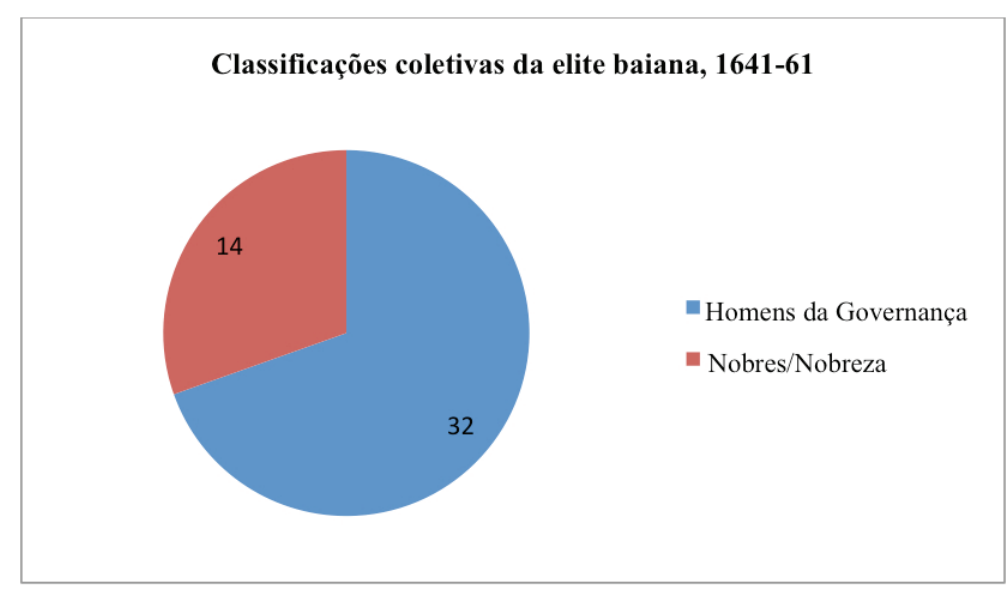

Fontes: AC, vols. II e III (p. 27-186).

Entretanto, a flexibilidade e indeterminação nominativa continuaram. Entre 1641 e 1651, por exemplo, de 46 casos, 32 fazem referências aos "homens da governança" e suas variações ou aos cidadãos, em oposição a 14 casos em que se mencionam nobres ou nobreza, ${ }^{25} \mathrm{um}$ aumento de mais de $50 \%$ em relação ao período anterior. Embora as expressões designem o mesmo grupo, a partir de 1631, há uma especificidade: "nobres" e "nobreza" são termos que aparecem quase exclusivamente em assuntos de maior importância, como o sustento da infantaria e a necessidade de uma moeda provincial - sempre, cabe notar, em diálogo com o governador geral. As outras designações, por sua vez, predominam em assuntos rotineiros, como eleições e regulação cotidiana do mercado. ${ }^{26}$ Tal divisão não é, porém, absoluta, podendo ser apontadas exceções, especialmente na convocação de "homens da governança" para assuntos de maior importância. A "nobreza", porém, raramente aparece em temáticas do cotidiano. Por ser esse um termo de maior significado simbólico que "homens de governança", o conceito "nobreza" era acionado nas questões políticas mais importantes para a elite baiana. Dada a importância

\footnotetext{
${ }^{25}$ AC, vol. II, p. 10-16, 23-6, 28-30, 35-9, 45-6, 55-7, 70-4, 91-4, 101-2, 104-5, 112-4, 124-7, 162-3, 167-8, 175-8, 183-5, 187-8, 214-5, 230-1, 237-8, 265-6, 281, 295-6, 298-9, 303, 315-6, 321-6, 33840 e 349; vol. III, p. 27-30, 35-7, 61-3, 88-95, 98-100, 102-3, 127-8, 131-4, 140-3 e 150-4.

${ }^{26}$ Cf., por exemplo, AC, vol. I, p. 211, 236-7, 281-3 e 341; vol. II, p. 214-5, 295-6, 298-9 e 310-1; vol. III, p. 127-8, 131-4, 296-7, 306-7 e 311-4.
} 
das atas na memória administrativa camarária, é provável que a reunião da "nobreza" ou dos "nobres" com os camaristas desse maior legitimidade às decisões tomadas pela municipalidade.

Em finais de 1651, surge a mais clara enunciação até então de um modelo tripartido aplicado à política baiana: o "Assento que se tomou em Câmara com os estados Clero, Nobreza e Povo sobre as patacas correrem ou não haverem de correr", quando se reuniram com os camaristas "os três estados desta República, Clero, Nobreza e Povo", em reação a uma carta régia sobre a proibição das patacas do Peru e os problemas gerados pela falta de moeda. Pede-se, assim, a anulação da provisão para o governador geral, que concorda com os camaristas. ${ }^{27} \mathrm{O}$ assento foi considerado relevante a ponto de merecer o envio de uma cópia para o Conselho Ultramarino, de modo a abalizar a decisão da Coroa $^{28}$ - procedimento excepcional, poucas vezes repetido no século XVII.

Sem a presença do clero, mas com a participação da "nobreza e povo", é assinado o acordo pela qual a Câmara institucionalizou, em 14 de julho de 1652, a situação vigente há mais de 20 anos, isto é, sua responsabilidade pelo sustento da infantaria. ${ }^{29}$ Tal ocasião se provou de uma importância notável, pois passou a ser citada nas dezenas de cartas da municipalidade sobre as obrigações fiscais da Câmara ao longo de todo o restante do século, de modo que, praticamente de forma anual, os camaristas se referiam a um documento legitimado pela presença e participação da nobreza local. É de se notar que, nessa época, o estatuto de nobreza já era reconhecido pelo governador geral, como no caso de uma portaria do conde de Castel-Melhor considerada relevante o suficiente para ser registrada nas atas logo antes do documento acima, no qual o alter-ego do monarca na América afirma esperar "que a nobreza e povo desta cidade tenha entendido" a importância do cuidado e correção nos dispêndios para sustento da infantaria. ${ }^{30}$ Entretanto, mesmo após estes documentos emblemáticos, a nobreza não passou a ser a denominação preferida da elite baiana. Entre 1652 e 1661, de doze casos, em apenas dois há referência à nobreza - e em ambos os momentos tratava-se de questões fiscais. ${ }^{31}$

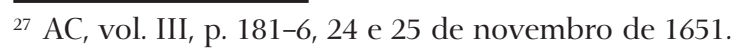

${ }^{28}$ Oficiais da Câmara de Salvador. Assento sobre a nova lei das patacas. 25 de novembro de 1651. AHU, Bahia, LF, cx. 12, docs. 1465.

${ }^{29}$ AC, vol. III, p. 212-20.

${ }^{30}$ AC, vol. III, p. 210-1.

${ }^{31} A C$, vol. III, p. 223-6, 266-7, 271-3, 280-1, 296-7, 306-7, 320-2, 353-5, 397-400, 412-3 e vol. IV, p. 91-3; Documentos históricos do Arquivo Municipal: Cartas do Senado, 6 vols. (1648-1730). Salvador: Prefeitura Municipal, 1951-84 (doravante CS), vol. I, p. 55-6.
} 


\section{A ascensão da nobreza?}

Entre 1662 e 1700, porém, de 121 referências ao grupo dominante concentrado em torno do Senado, "nobres" e principalmente "nobreza" predominam, com 87 casos, contra 34 variações de "homens da governança" e "cidadãos" - esses aparecendo principalmente nos momentos de eleições, já que estas, por definição, são responsabilidade daqueles ligados ao poder municipal e não exatamente de um grupo social, apesar da relativa indistinção entre as duas categorias. Em menor escala, o termo cidadão também é onipresente nas referências aos privilégios de cidadão da Cidade do Porto, já que estes foram concedidos aos "cidadãos" de Salvador.

\section{Gráfico 3}

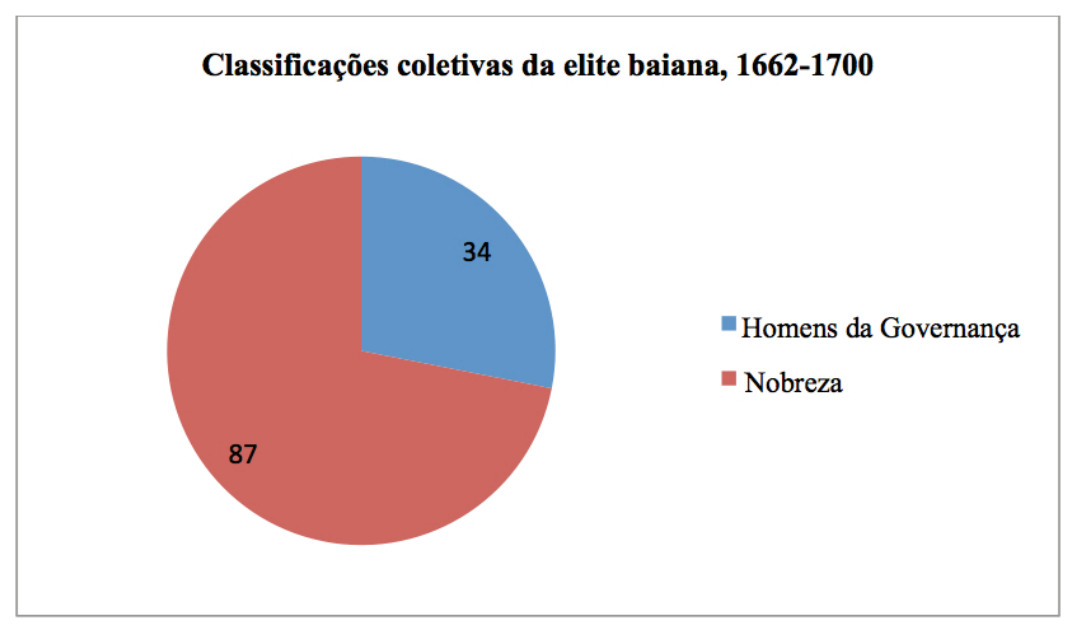

Fontes: AC, vols. IV-VI; CS, vols. I-IV; Oficiais da Câmara de Salvador. Carta ao rei d. Afonso VI. 28 de agosto de 1663. AHU, Bahia, LF, cx. 17, doc. 1950; Oficiais da Câmara de Salvador. Carta ao rei d. Afonso VI. 13 de agosto de 1666. Idem, cx. 19, doc. 2147; Oficiais da Câmara de Salvador. Carta ao príncipe regente d. Pedro. 28 de janeiro de 1668. Idem, cx. 20, doc. 2238; Oficiais da Câmara de Salvador. Carta ao príncipe regente d. Pedro. 15 de abril de 1676. Idem, cx. 23, doc. 2709.

Na maioria das vezes, pontos de corte muito definidos são enganosos, já que escondem continuidades e processos anteriores. Ainda em 1697, por exemplo, "homens bons" e "nobreza" são termos utilizados numa ata em 
que se discute o preço da farinha. ${ }^{32}$ A diferença, porém, entre os períodos de 1625-1661 e 1662-1700 parece clara, mesmo que represente antes a consolidação e intensificação de um processo de longo prazo e não uma brusca ruptura. Considerando que o termo "nobreza" aparece com mais frequência quando se tratava da fiscalidade e de pedidos do governador geral, o ponto a marcar o início desta segunda fase foi a cobrança do donativo para dote da rainha da Grã-Bretanha e paz de Holanda, importante tributo administrado pelas câmaras americanas. Para resolver a distribuição dos valores da contribuição, o "Senhor Francisco Barreto do seu Conselho de Guerra, Governador e Capitão Geral do Estado do Brasil ordenou se achassem o Senado da Câmara e nobreza e povo dela em minha presença", em 24 de fevereiro de $1662 .^{33}$

Assim, ao longo do século XVII, "nobreza" passou de um termo raramente utilizado para conceito predominante na autorrepresentação da elite baiana, que chega a produzir um longo "Protesto da Nobreza da Cidade da Bahia ao Senado da Câmara para a fazer presente a sua Majestade", demandando a implantação da moeda provincial, com apoio do clero e do povo. ${ }^{34}$ A partir de 1663 (e a coincidência de datas com o início da cobrança do donativo não deve ser fortuita), "nobreza e povo" passaram mesmo a ter sua presença registrada nas cerimônias de pleito e homenagem prestadas aos governadores que tomavam posse..$^{35}$

Os fatores que parecem ter contribuído para esse fenômeno são múltiplos. A consolidação da posição soteropolitana como "cabeça do Estado do Brasil", ou seja, uma importante cidade, em termos comerciais, mas, principalmente, políticos, dotada de preeminências sobre o restante da América portuguesa, pode ter sido um elemento essencial: afinal, era na "cidade da Bahia" que a elite era capaz de agir coletivamente como nobreza, através do exercício efetivo do poder político e da expressão simbólica e ritual de sua preeminência social através das festas e procissões. ${ }^{36}$ Por outro lado, a

\footnotetext{
32 AC, vol. VI, p. 352-4.

${ }^{3}$ AC, vol. IV, p. 136-40. Cf. também Documentos históricos da Biblioteca Nacional do Rio de Janeiro. Rio de Janeiro: Biblioteca Nacional, 1928-2011, 112 volumes (doravante DH), vol. 4, p. 97-100 e vol. 5, p. 344-8.

${ }^{34}$ CS, vol. IV, p. 3-10; cf. também p. 10-12 e 14, assim como vol. III, p. 114-7.

${ }^{35}$ DH, vol. 21, p. 112; vol. 23, p. 9 e vol. 24, p. 157.

${ }^{36}$ Cf. SCHWARTZ, Stuart. The king's processions: Municipal and royal authority and the hierarchies of power in colonial Salvador In: ROCKEY, Liam Matthew (org.). Portuguese colonial cities in the early modern world. Aldershot: Ashgate, 2008, p. 177-204.
} 


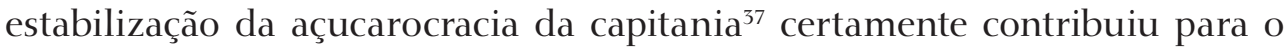
resultado, graças ao surgimento de importantes famílias ligadas e opostas por laços de parentesco e aliança.

No entanto, no âmbito do discurso e da prática política, os aspectos determinantes no processo foram, em primeiro lugar, a pressão fiscal da Coroa, e, em seguida, o relacionamento com os governadores gerais e o monarca. A necessidade de deliberar sobre temas de grande importância para a capitania, como uma carga tributária que girava em torno de 100.000 cruzados anuais em contribuições administradas pelo Senado - somando-se o donativo com o sustento da infantaria - exigia que a Câmara consultasse os membros da elite para obter legitimidade para suas ações, e o grupo, ao representar-se como uma nobreza, presumivelmente ganhava força política, pois essa identidade representava "um elemento e instrumento com o qual os estratos sociais superiores buscavam defender sua distinção e exclusividade social". ${ }^{38}$ Da mesma maneira, a adoção dos modelos reinóis na negociação com a Coroa e, principalmente, seus representantes na América reforçava a posição da elite baiana como um agente político de grande relevância.

Por último, era esse o modelo que traziam do reino e, por mais que a sociedade escravista em que viviam tenha transformado decisivamente os aspectos sociais e econômicos da constituição das elites ultramarinas - senhoras, afinal, de muitos cativos, o que implicava problemas e possibilidades inexistentes em Portugal, assim como dependentes do mercado externo para sua própria reprodução social ${ }^{39}$ - o modelo político-ideológico que traziam era ibérico, e é de acordo com essa visão de mundo que as elites brasílicas vão procurar crescentemente se apresentar. A identidade nobiliárquica local surge tanto a partir da ascensão socioeconômica da açucarocracia quanto das relações por ela estabelecidas com o poder monárquico e sua administração periférica. Desse modo, "nobre e nobreza se provam como conceitos relacionais e situacionais, definidos por mecanismos de aceitação tanto pelos pares quanto pelo meio social e político mais amplo".40

É provável que a aceitação pelos governadores dessas pretensões reforçasse essa identidade, como nos casos supracitados de Castel-Melhor e Francisco

\footnotetext{
37 Sobre sua constituição, cf. RICUPERO, Rodrigo. A formação da elite colonial. Brasil, c. 1530 - c. 1630. São Paulo: Alameda, 2008.

38 BÜSCHGES, Christian. Introducción. In: Idem eSCHRÖTER, Bernd. (eds.), op. cit., p. 13, tradução minha.

39 FRAGOSO, João, op. cit., passim.

${ }^{40}$ LEONHARD, Jörn e WIELAND, Christian. Noble identities from the sixteenth to the twentieth century. In: Idem (eds.). What makes the nobility noble? Göttingen: Vandenhoeck $\mathcal{E}$ Ruprecht, 2011, p. 25-6.
} 
rev. hist. (São Paulo), n. 170, p. 201-232, jan.-jun., 2014 http://dx.doi.org/10.11606/issn.2316-9141.v0i170p201-232
Thiago Nascimento Krause

De homens da governança à primeira nobreza: vocabulário social e transformações estamentais na Bahia seiscentista

Barreto, assim como, posteriormente, de Alexandre de Sousa Freire. ${ }^{41}$ Referências do tipo não estão presentes apenas na correspondência para a Câmara, mas também para o monarca, como em missiva do citado Castel-Melhor. ${ }^{42}$

Até um letrado castelhano residente na Bahia, autor de um singular panegírico fúnebre ao governador d. Afonso Furtado de Mendonça, menciona três vezes em sua obra a "nobreza" da Bahia como um corpo coeso. ${ }^{43}$ Poucos anos depois, outro letrado, este baiano e bem mais conhecido, menciona diversas vezes a nobreza - e certamente estava familiarizado com o discurso camarário, pois serviu como procurador da municipalidade soteropolitana: o poeta Gregório de Matos. ${ }^{44} \mathrm{O}$ "Boca do Inferno" lamenta a morte do coronel Afonso Barbosa de França (falecido em inícios de 1679), "mancebo generoso, da principal nobreza da Bahia" ${ }^{\prime 45}$ e, noutro poema, menciona que, junto com o governador geral e os padres, "toda a nobreza" assistiu a festas "em louvor das onze mil virgens".

Da mesma maneira, Sebastião da Rocha Pitta, ao narrar as manifestações em Salvador após o falecimento de d. Pedro II, menciona o "numeroso concurso da Nobreza e Povo". Já na licença do livro, o famoso conselheiro ultramarino Antônio Rodrigues da Costa enfatiza a participação da "Nobreza da Cidade da Bahia" nas exéquias do monarca. ${ }^{46}$ Publicava-se, assim, uma prática longamente estabelecida, pois o registro da Câmara da cerimônia de quebra dos escudos após as mortes de d. João IV e d. Afonso VI já enfatizava a participação coletiva da nobreza na procissão funerária saída do Senado, ${ }^{47}$ assim como

${ }_{41}$ DH, vol. 86, p. 162; registrado nas AC, vol. IV, p. 383-4. Cf. também DH, vol. 3, p. 55 e vol. 4, p. 304-5.

${ }^{42}$ Conselho Ultramarino. Consulta ao rei. d. João IV. 29 de julho de 1650. AHU, cód. 14, fl. 244v.

43 SCHWARTZ, Stuart e PÉCORA, Alcir (org.). As excelências do governador: o panegírico fúnebre a d. Afonso Furtado, de Juan Lopes Sierra (Bahia, 1676). Tradução. São Paulo: Companhia das Letras, 2002, p. 200, 229 e 255. Há que se notar que o próprio Afonso Furtado da Mendonça incluíra membros da "nobreza" na junta que reuniu para decidir sobre sua sucessão: DH, vol. 88, p. 85 e 103.

${ }^{44}$ Cf. AC, vol. V, p. 70, 108 e 143; cf. também CS, vol. II, p. 17 e PERES, Fernando da Rocha. Gregório de Mattos: o poeta devorador. Rio de Janeiro: Manati, 2004, p. 74.

${ }^{45}$ Cf. TOPA, Francisco. Edição crítica da obra poética de Gregório de Matos. Tese de doutorado, Faculdade de Letras, Universidade do Porto, 1999, vol. II, p. 235-7.

${ }^{46}$ PITTA, Sebastião da Rocha. Breve compêndio e narração do fúnebre espetáculo que na insigne cidade da Bahia, cabeça da América portuguesa, se viu na morte de el-rey d. Pedro II, de gloriosa memória, senhor nosso. Lisboa: Oficina de Valentim da Costa Deslandes, 1709, licença e p. 15. O tio do autor, o desembargador João da Rocha Pita, utiliza diversas vezes o coletivo "nobreza" ao explicar as tensões políticas do assassinato do alcaide-mor Francisco Teles de Meneses em 1682. DH, vol. 88, p. 264-7.

${ }^{47}$ Oficiais da Câmara de Salvador. Assento da quebra de escudos na morte do rei d. João IV. 16 de fevereiro de 1657. Arquivo Histórico Municipal de Salvador (doravante AHMS), Provisões reais (PR), vol. II, fls. 44-45v e Oficiais da Câmara de Salvador. Assento da quebra de escudos na morte do rei d. Afonso VI. 22 de dezembro de 1683. Idem, vol. III, fls. 24-25. 
rev. hist. (São Paulo), n. 170, p. 201-232, jan.jun., 2014 http://dx.doi.org/10.11606/issn.2316-9141.v0i170p201-232
Thiago Nascimento Krause

De homens da governança à primeira nobreza: vocabulário social e transformações estamentais na Bahia seiscentista

na aclamação de d. Pedro II, que ocorreu "em presença de toda a nobreza", tomando esta parte ativa no ritual, juntamente com os oficiais da Câmara. ${ }^{48}$

Na obra mais conhecida de Rocha Pitta, a História da América portuguesa, o termo é onipresente, aparecendo dezenas de vezes. Há inclusive um esforço explícito de defender a existência de nobrezas ultramarinas, originárias de "muitos sujeitos oriundos de nobilíssimas casas de Portugal e, sendo ramos de generosos troncos transplantados a este clima, produziram frutos de continuada descendência, que não degeneram das suas origens, antes as acreditam" ${ }^{49}$ Exatamente em razão dessa vaga ficção genealógica lhe foi possível conceber tal nobreza como eterna, não dotada de um início, estando já plenamente constituída quando da morte do governador geral Lourenço da Veiga em 1581 e aparecendo em vários dos já citados momentos de grande significação política da história baiana: a aclamação de d. João IV, a divisão do donativo de dote e paz, a fundação do convento das clarissas e a sucessão dos governadores-gerais Afonso Furtado de Mendonça e Matias da Cunha.

Também alguns dos principais mecanismos de legitimação do status das elites portuguesas chegaram a afirmar a existência de uma nobreza baiana, mesmo que tentativamente: as inquirições das ordens militares e do Santo Ofício. Na habilitação para a Ordem de Cristo de João Soares Brandão, por exemplo, a Mesa de Consciência e Ordens afirma que o postulante "é da melhor nobreza que há na Bahia de Todos os Santos". ${ }^{50}$ Se esse é um caso em que há referência a uma coletividade, todas as habilitações da elite baiana contêm em si elementos de um discurso genealógico a enfatizar a nobreza individual e familiar, pois era este o interesse dos inquiridores. Na própria Bahia de meados do século, os cargos no governo na República eram referidos em meados do século como "ofícios nobres" e os irmãos de maior condição da Misericórdia como "do número dos nobres", como se vê no tes-

\footnotetext{
${ }^{48}$ Oficiais da Câmara de Salvador. Assento da Aclamação de d. Pedro II, rei de Portugal. 23 de dezembro de 1683. AHMS, PR, vol. III, fls. 25v-26.

${ }^{49}$ PITTA, Sebastião da Rocha. História da América portuguesa. Lisboa: Oficina de Joseph Antônio da Silva, 1730, p. 132-3.

${ }^{50}$ Mesa da Consciência e Ordens. Consulta ao rei d. Afonso VI, 19 de dezembro de 1665. Instituto dos Arquivos Nacionais/Torre do Tombo, Habilitações da Ordem de Cristo, letra J, maço 93, n. 62. Cf. também Idem, Desembargo do Paço, Leitura de bacharéis, 1644. letra C, maço 2, n. 55 (Cristóvão de Burgos); Tribunal do Santo Ofício, Conselho Geral, Habilitações de familiares, 1671-89, Sebastião, maço 4, n. 97 (Sebastião de Brito de Castro).
} 
rev. hist. (São Paulo), n. 170, p. 201-232, jan.-jun., 2014 http://dx.doi.org/10.11606/issn.2316-9141.v0i170p201-232
Thiago Nascimento Krause

De homens da governança à primeira nobreza: vocabulário social e transformações estamentais na Bahia seiscentista

temunho do velho fidalgo Diogo de Aragão Pereira na leitura de bacharel de Gregório de Matos Guerra, repetida por todos os outros depoentes. ${ }^{51}$

Um curioso documento talvez evidencie a disseminação dessa forma de classificação no discurso corrente: em denúncia à Inquisição de 23 de dezembro de 1667, o chantre da Sé da Bahia, Domingos Vieira de Lima, acusou o licenciado JoséPinto de Freitas, tesoureiro-mor da Sé, de cometer o pecado nefando, "do qual há fama pública e constante entre a plebe, clérigos, religiosos e nobreza", tanto que, dentre as testemunhas que aponta, arrola genericamente "toda a nobreza". ${ }^{2}$

A própria Coroa reconhecia a existência de uma nobreza baiana, ao permitir, por exemplo, a fundação de um convento de freiras em Salvador a pedido dos "oficiais da Câmara, Nobreza e Povo", numa provisão de 7 de fevereiro de $1665 .^{53}$ Em primeiro de julho do ano seguinte, em resposta a uma representação do procurador da Bahia em Lisboa, o monarca decide que "a eleição dos ministros da junta [para decidir a cobrança do donativo] se faça cada três anos pela nobreza, povo e eclesiástico". ${ }^{54}$

Emblemática nesse sentido é uma resolução de d. Pedro II sobre a tentativa de dois homens de negócio de se isentar de servir como procuradores da Câmara, utilizando como justificativa o fato de serem cavaleiros da Ordem de Cristo. Em 23 de março de 1686, o monarca decidiu que "na Bahia não se faça eleição de nenhum dos cavaleiros das três Ordens para ofício de procurador, visto que para estes cargos se não costuma eleger as pessoas da primeira nobreza, que servem de juízes e vereadores, se não outras de diferente qualidade". ${ }^{55}$ Assim, em finais do século XVII, ninguém colocava em dúvida a existência de um grupo social superior estamentalmente constituído como coletividade na Bahia.

\footnotetext{
${ }^{51}$ FONSECA, Luiza da. Bacharéis brasileiros: elementos biográficos. IV CONGRESSO DE HISTÓRIA NACIONAL. Anais. Rio de Janeiro: Imprensa Nacional, 1951, vol. IX, p. 143-63.

${ }^{52}$ Chantre Domingos Vieira de Lima. Denúncia. 23 de dezembro de 1667. Instituto dos Arquivos Nacionais/Torre do Tombo, Inquisição de Lisboa, Cadernos do Nefando, n. 12, fls. 107-107v.

${ }^{53}$ D. Afonso VI. Provisão. 7 de fevereiro de 1665. AHMS, PR, vol. II, fls. 98-102.

${ }^{54}$ Conselho Ultramarino. Consulta ao rei d. Afonso VI. 5 de maio de 1666. AHU, cód. 16, fl. $201 \mathrm{v}$. Cf. também D. Afonso VI. Provisão. 12 de julho de 1666. AHMS, PR, vol. II, fls. 90v-93.

${ }^{55}$ Carta para o governador em DH, vol. 89, p. 49-52 e, para a Câmara, em D. Pedro II, carta para a Câmara de Salvador. 3 de abril de 1686. AHMS, PR, vol. III, fl. 36v. Para os desdobramentos posteriores, cf. D. Pedro II. Provisão. 12 de janeiro de 1692. AHMS, PR, vol. III, fls. 63-64.
} 


\section{Os privilégios da nobreza baiana}

Esse reconhecimento gerava efeitos práticos. De acordo com H. M. Scott e C. Storrs, "nos séculos XVII e XVIII a 'nobreza' era um grupo específico dentro da sociedade distinguido primariamente pelos privilégios sociais e legais que gozava e por sua posição como terratenentes importantes e frequentemente dominantes". ${ }^{56}$ Quanto ao papel da açucarocracia como latifundiária, não há o que acrescentar. ${ }^{57}$ Uma análise sobre seus privilégios, porém, é fundamental para entender o que significou a constituição de uma nobreza na cabeça da América portuguesa.

Ainda segundo Scott e Storrs, "os privilégios nobiliárquicos eram muitos e variados. Uma categoria importante garantia à nobreza o direito de participar em e, na prática, dominar a vida política". ${ }^{58}$ Como se evidencia das páginas acima, a constituição estamental da elite baiana passa diretamente pelo exercício do poder através da Câmara. Torna-se possível, assim, para este grupo governar a República e atuar como interlocutor único dos representantes da administração periférica e do próprio monarca. Assim, o controle dos cargos políticos locais que havia possibilitado a constituição da nobreza é reforçado pelo avanço do discurso estamental. Em acréscimo, tal domínio estendia-se para todos os postos de poder e prestígio em Salvador, como os principais cargos da Misericórdia, de oficialato na ordenança e nas Ordens Terceiras do Carmo e São Francisco - ainda que possibilidades de inclusão de forasteiros tenham sempre existido, especialmente de ricos comerciantes e influentes desembargadores. ${ }^{59}$

O comando político da localidade não era, porém, o único privilégio gozado coletivamente pela nobreza. Já em 1630, a elite baiana demandou os

\footnotetext{
${ }^{56}$ SCOTT, Hamish e STORRS, Christopher. The consolidation of noble power in Europe, c. 16001800. In: SCOTT, Hamish (ed.). The European nobilities in the seventeenth and eighteenth-centuries, vol. 1: Western and southwestern Europe. $2^{\mathrm{a}}$ ed. rev. e ampliada. Nova York: Palgrave Macmillan, 2007, p. 9, tradução minha.

57 SCHWARTZ, Stuart. Segredos internos: engenhos e escravos na sociedade colonial, 1550-1835. Tradução. São Paulo: Companhia das Letras, 1988, p. 224-46.

${ }^{58}$ SCOTT, Hamish e STORRS, Christopher, art. cit., p. 9, tradução minha.

${ }^{59}$ FLORY, Rae e SMITH, David Grant. Bahian merchants and planters in the seventeenth and early eighteenth centuries. The Hispanic American Historical Review, Durham, vol. 58, n. 4, novembro de 1978, p. 571-94, http://dx.doi.org/10.2307/2513341, e SCHWARTZ, Stuart B. Burocracia e sociedade no Brasil colonial: a Suprema Corte da Bahia e seus juízes (1609-1751). Tradução. São Paulo: Perspectiva, 1979, p. 251-95.
} 
rev. hist. (São Paulo), n. 170, p. 201-232, jan.-jun., 2014 http://dx.doi.org/10.11606/issn.2316-9141.v0i170p201-232
Thiago Nascimento Krause

De homens da governança à primeira nobreza: vocabulário social e transformações estamentais na Bahia seiscentista

privilégios dos infanções medievais, mas sem sucesso. ${ }^{60}$ Após a Restauração portuguesa, porém, os camaristas voltaram à carga em 1643 e pediram os privilégios de cidadãos da cidade do Porto, enfatizando ser Salvador "a cabeça de todo o Estado do Brasil" e merecedora de honras pelos muitos serviços prestados - maiores, certamente, do que a Câmara de São Luís, que acabara de receber esta mercê logo após a vitória contra os holandeses. Receberam o enfático apoio do recém-fundado Conselho Ultramarino em razão das "muitas vexações e moléstias que de anos a esta parte tem padecido" e das "outras muitas contribuições que tem feito e fazem em todo o tempo que tem ido e vão armadas de Vossa Majestade, além de contribuições, donativos e imposições voluntárias para sustento e paga do presídio que Vossa Majestade tem naquela cidade". O procurador da Coroa reforçou esse parecer, sugerindo ainda que a Bahia recebesse o direito de representação nas Cortes, aproveitando o ensejo do pedido goês neste sentido, para que ambas as cidades fossem situadas no primeiro banco, juntamente com as municipalidades mais prestigiosas do reino. ${ }^{61}$ Assim, em 22 de março de 1646, são concedidos os privilégios da cidade do Porto aos cidadãos de Salvador ${ }^{62}$ e nas Cortes de 1653 seu procurador já se faz presente em razão de sua posição como "cabeça do Estado", ainda que no segundo banco, atrás de Goa - situação só remediada em 1674, com a "promoção" de Salvador ao primeiro banco, após uma petição da Câmara. ${ }^{63}$

Salvador incluía-se, assim, definitivamente, entre as cidades e vilas notáveis do mundo português nesse momento de legitimação da nova dinastia e defesa do reino e império. Mais importante, o avanço desses privilégios de representação acompanhava o avanço da própria estruturação da elite como nobreza: afinal, uma cidade notável não poderia ter como grupo dominante senão uma nobreza.

Estes privilégios incluíam elementos característicos da condição nobiliárquica, como proteção judicial na maioria das circunstâncias contra prisão, tortura ou punições infamantes, além da possibilidade de portar armas. Tais

\footnotetext{
${ }^{60}$ SILVA, José Justino de Andrade e. Collecção chronológica da legislação portugueza. Lisboa: Imprensa de J. J. A. Silva, 1854-9, 11 volumes (doravante CCLP), vol. 4, p. 249.

${ }^{61}$ Conselho Ultramarino. Consulta ao rei d. João IV. 3 de março de 1646. AHU, Bahia, LF, cx. 10, docs. 1176-1177.

62 Traslado dos privilégios que sua majestade concedeu aos cidadãos da Bahia de Todos os Santos. In: Revista do Instituto Histórico e Geográfico Brasileiro. $2^{\text {a }}$ ed. Tomo VIII, 1867, p. 512-26.

${ }^{63}$ CARDIM, Pedro. The representatives of Asian and American cities at the Cortes of Portugal; In: Idem; HERZOG, Tamar; RUIZ IBÁNEZ, José Javier e SABATINI, Gaetano (eds.). Polycentric monarchies: How did early modern Spain and Portugal achieve and maintain a global hegemony? Eastbourne: Sussex Academic Press, 2012, p. 43-53.
} 
rev. hist. (São Paulo), n. 170, p. 201-232, jan.jun., 2014 http://dx.doi.org/10.11606/issn.2316-9141.v0i170p201-232
Thiago Nascimento Krause

De homens da governança à primeira nobreza: vocabulário social e transformações estamentais na Bahia seiscentista

prerrogativas foram ardorosamente defendidas pela Câmara em 1651, 1656, 1672 e 1697, que frequentemente pedia respeito a elas contra dúvidas dos desembargadores da Relação, do governador geral e do próprio monarca, tendo sido geralmente bem-sucedida nesses esforços. ${ }^{64}$ Outro elemento característico dos estamentos superiores era o direito de ostentar sua posição em cerimônias públicas, como festas e procissões - privilégio também defendido diversas vezes pelo Senado. ${ }^{65}$ Considerando a importância da representação visual na afirmação das hierarquias sociais na Época Moderna, não é um grande passo inferir que essas cerimônias ajudavam a consolidar a nobreza baiana como grupo, já que, através delas, a elite podia se apresentar e ser publicamente reconhecida como tal.

Em acréscimo, o período crucial de formação do discurso nobiliárquico baiano, entre 1640 e 1680, também conheceu um grande aumento da participação da elite da capitania na economia da mercê e na obtenção de honrarias nobilitantes: pelo menos 50 senhores de engenho pediram hábitos das ordens militares e 33 se tornaram cavaleiros; cerca de um quarto dos camaristas, entre 1641 e 1683, também requereu a insígnia de uma das ordens como recompensa por seus serviços ao monarca, e 32 dos 38 provedores da Misericórdia do período conseguiram hábitos para si ou seus filhos. ${ }^{66}$ Da mesma maneira, todos os coronéis da ordenança foram cavaleiros da milícia tomarense. Se utilizarmos como base de comparação as ordens militares, portanto, Salvador está numa posição vantajosa frente a outras regiões americanas, como a Nova Espanha, e até europeias, como Évora, pois parcela considerável de sua elite foi nobilitada no período, enquanto "apenas 50 residentes permanentes na Nova Espanha entraram em alguma das ordens antes de 1700", mesmo sendo esta região dotada de uma população significativamente mais numerosa do que a da Bahia. ${ }^{67}$ Tal situação se deu devido ao engajamento da elite baiana na defesa de sua capitania, dotada de grande valor estratégico como "cabeça do Estado do Brasil" e principal polo açucareiro depois da invasão de Pernambuco em 1630, e, consequentemente, da

\footnotetext{
${ }^{64}$ D. João IV. Carta ao governador geral conde de Castel-Melhor. 5 de setembro de 1652. AHMS, PR, vol. II, fls. 31v-32; CS, vol. I, p. 55-6; “Traslado", art. cit., p. 524; Conselho Ultramarino. Consulta ao príncipe regente d. Pedro. 8 de novembro de 1672. AHU, cód. 17, fls. 68v-69 e CS, vol. IV, p. 76-7.

${ }^{65}$ CS, vol. I, p. 18-21; Câmara de Salvador. Carta ao rei d. Afonso VI. 28 de agosto de 1663. AHU, Bahia, LF, cx. 17, doc. 1945.

${ }^{66}$ KRAUSE, Thiago Nascimento, op. cit., p. 169-246.

${ }^{67}$ KICZA, John. Formación, identidade y estabilidade dentro de la elite colonial mexicana en los siglos XVI y XVII. In: SCHRÖTER, Bernd e BÜSCHGES, Christian (eds.), op. cit., p. 26.
} 
valorização dos seus serviços pela Coroa lusa, passando a receber até mais mercês que Pernambuco a partir da regência de d. Pedro (1667-83), com o fim da Guerra de Restauração contra a Espanha (1668) e da ameaça neerlandesa após a efetivação do acordo de paz (1661-9). ${ }^{68}$

Fossem individuais ou coletivos, tais privilégios certamente eram muito inferiores aos gozados pelas aristocracias europeias. Entretanto, as nobrezas provinciais reinóis gozavam tão somente das mesmas prerrogativas que a elite baiana, inclusive no Porto, a segunda Câmara mais importante de Portugal. ${ }^{69}$ Como já notou Fernanda Bicalho, "a concessão de honras e privilégios às Câmaras Municipais, fosse no Reino, fosse especificamente no ultramar, correspondeu a um processo de nobilitação de seus componentes".70 Nesse ponto, é difícil traçar distinções precisas entre as nobrezas provinciais na Europa e na América, especialmente a partir do momento em que estas começaram a se consolidar nas principais regiões, na segunda metade dos Seiscentos. Aqui, como lá, "reservava-se o exercício de poderes que interessavam ao rei a camadas sociais assinaláveis, dotadas de sentido de honra e vivendo à lei da nobreza, que se satisfazia com a aproximação a privilégios dos estratos superiores da aristocracia - nomeadamente penais".71 Talvez os vassalos das conquistas pudessem mesmo contar com algumas vantagens, já que desde o início do século a açucarocracia obteve o privilégio de que seus engenhos seriam executados pelos credores apenas em seus rendimentos. ${ }^{72}$

\section{De classe para estamento?}

Evaldo Cabral de Mello enxergou um processo de "metamorfose da açucarocracia em 'nobreza da terra'", 73 afirmando que, apesar dos elementos classistas presentes na elite açucareira, ela se pensava e era vista como estamento. ${ }^{74}$ Por outro lado, Stuart Schwartz também demonstrou o quanto esse grupo era capaz de "agir de modo coeso como uma classe com interesses e

\footnotetext{
${ }^{68}$ KRAUSE, Thiago Nascimento, op. cit., p. 93-168.

${ }^{69}$ Cf. SILVA, Francisco Ribeiro da, op. cit., p. 286-306.

${ }^{70}$ BICALHO, Maria Fernanda. A cidade e o império: o Rio de Janeiro no século XVIII. Rio de Janeiro: Civilização Brasileira, 2003, p. 324.

${ }^{71}$ MAGALHÃES, Joaquim Romero, Os nobres..., art. cit., p. 69.

72 CCLP, vol. II, p. 130-1, vol. IV, p. 249 e vol. X, p. 7; D. Afonso VI. Provisão. 23 de dezembro de 1663. AHMS, PR, vol. II, 68v-70v.

73 MELLO, Evaldo Cabral de, Rubro veio, op. cit., p. 157.

${ }^{74}$ MELLO, Evaldo Cabral de, A fronda dos mazombos, op. cit., p. 18.
} 
rev. hist. (São Paulo), n. 170, p. 201-232, jan.jun., 2014 http://dx.doi.org/10.11606/issn.2316-9141.v0i170p201-232
Thiago Nascimento Krause

De homens da governança à primeira nobreza: vocabulário social e transformações estamentais na Bahia seiscentista

objetivos próprios, assumindo papéis políticos e procurando influenciar a política régia e municipal", peticionando como um grupo mobilizado. ${ }^{75}$

Estas duas visões não são opostas, mas complementares. Retornando a Max Weber, somos lembrados de que "as distinções de classe estão ligadas, das formas mais variadas, com as distinções de estamento". ${ }^{76}$ Entendo classe aqui como uma situação de mercado, classificando indivíduos e grupos a partir de sua relação com os meios de produção, atividade econômica e nível de riqueza, enquanto o conceito de estamento representa outra forma de hierarquização baseada na honra, no estilo de vida e em distinções que estabelecem diferenças juridicamente relevantes através da atribuição de privilégios. ${ }^{77}$

A açucarocracia baiana podia se comportar como estamento; como vimos, era mesmo nesse registro que ela preferencialmente se representava. Uma identidade, porém, não excluía a outra, como é demonstrado por sua capacidade de se mobilizar em defesa de interesses de classe comuns. Em 1632, em uma longa petição dos "senhores de engenho e lavradores" de cana da capitania para o governador e a Coroa, pode ser lida como uma lista parcial dos homens da governança, como o fidalgo Diogo de Aragão Pereira, e André Cavalo de Carvalho, Domingos Barbosa de Araújo, Belchior Brandão, Eusébio Ferreira, Felipe de Moura, Luiz de Melo de Vasconcelos - todos juízes ordinários e vereadores da Câmara - juntamente com outros que não faziam parte do grupo, mas com os quais tinham em comum a participação na produção açucareira, como o rico cristão-novo e senhor de engenho Diogo Lopes de Ulhoa. ${ }^{78}$ Em 1664, em carta à Coroa do procurador da cidade da Bahia, o doutor João de Góis de Araújo, além de defender os interesses do setor açucareiro, refere-se a outra petição de senhores e lavradores em 1656 ao conde de Atouguia. ${ }^{79}$ Muito mais comum, porém, é a decidida atuação institucional em defesa da produção açucareira através da Câmara, como é

\footnotetext{
75 SCHWARTZ, Stuart, Segredos internos, op. cit., p. 176.

${ }^{76}$ WEBER, Max. Classe, estamento, partido. In: Idem. Ensaios de Sociologia. Tradução. $5^{\mathrm{a}}$ ed. Rio de Janeiro: LTC, 1982, p. 220.

77 Cf. CARSTEN, Francis Ludwig. A nobreza de Brandeburgo e da Prússia dos séculos XVI a XVIII: ordem, casta ou classe social. In: MOUSNIER, Roland (org.). Problemas de estratificação social. Tradução. Lisboa: Cosmos, 1988, p. 199-220 e COLLINS, James B. Classes, estates, and order in early modern Brittany. Cambridge: Cambridge University Press, 1994. http://dx.doi. org/10.1017/СВО9780511562587.

${ }^{78}$ Senhores de engenho e lavradores da capitania da Bahia. Petição. 18 de março de 1632. AHMS, PR, vol. I, fls. 123-139v.

${ }^{79}$ Procurador João de Góis de Araújo. Carta ao rei d. Afonso VI. 13 de junho de 1664. AHU, Bahia, LF, cx. 18, doc. 2024.
} 
rev. hist. (São Paulo), n. 170, p. 201-232, jan.-jun., 2014 http://dx.doi.org/10.11606/issn.2316-9141.v0i170p201-232
Thiago Nascimento Krause

De homens da governança à primeira nobreza: vocabulário social e transformações estamentais na Bahia seiscentista

possível perceber nas trinta cartas do Senado especificamente sobre essa temática, quase todas após $1660^{80}$ - momento de consolidação do discurso nobiliárquico baiano, não custa lembrar. Nelas, a municipalidade reclama dos altos impostos, dos baixos preços do açúcar, das dificuldades de comércio e do endividamento dos produtores, pois sua preocupação era sempre com a ruína de "todos os senhores de engenho e lavradores de açúcar"81 - ou seja, com os efeitos da crise no grupo dominante da capitania.

Uma das questões abordadas nessas cartas, a controvérsia sobre a proibição de construção de mais engenhos no Recôncavo, oferece subsídios interessantes sobre esta questão. Primeiro, o provedor-mor - cavaleiro da Ordem de Cristo, fidalgo e senhor de engenho - Lourenço de Brito Correia escreveu que consultou os principais e estes produziram uma carta anexa, "o qual papel contém 108 pessoas principais, fidalgos, comendadores e cavaleiros do hábito e mais nobreza, e mestres de campo e oficiais de guerra, lavradores de cana, senhores de engenho, juízes ordinários e vereadores que servem". Vejamos então como os próprios principais se identificaram em sua missiva:

Nós, os abaixo assinados fidalgos da casa de Vossa Majestade e cavaleiros das três ordens militares, e homens nobres e da governança desta Cidade do Salvador, Bahia de Todos os Santos, e sua capitania e nela povoadores e moradores e provedores-mores da fazenda real e provedores da Fazenda e Juízes da Alfândega dela, e mais donos de engenhos de açúcar e lavradores de canas, e oficiais maiores do exército e presídio desta dita cidade, mestres de campo, tenentes de mestre de campo general, ajudantes de tenentes generais, e capitães de infantaria e sargentos-mores. ${ }^{82}$

No ano seguinte, em 1663, o sucessor de Correia, o cristão-novo, cavaleiro de Santiago e senhor de engenho Antônio Lopes Ulhoa escreveu "que em cumprimento da carta referida, relatou aos oficiais da Câmara a ordem

\footnotetext{
${ }^{80}$ CS, vol. I, p. 6-10, 72-3 e 114-5; CS, vol. II, p. 44-8, 99-100, 114-7 e 128-32; CS, vol. III, p. 5-6, 47-51, 62-72, 74-7, 82, 89-90, 96-8 e 112-4; CS, vol. IV, p. 64-6, 77-8 e 88-90; Câmara de Salvador. Carta ao rei d. João IV. 16 de setembro de 1642. AHMS, PR, vol. II, fls. 4v-6; Câmara de Salvador. Representação ao rei d. Afonso VI. 1 de junho de 1661. AHU, Bahia, Avulsos, cx. 2, doc. 128; Câmara de Salvador. Carta ao rei d. Afonso VI. 28 de agosto de 1663. Idem, LF, cx. 17, doc. 1951; Procurador João de Góis de Araújo. Carta ao rei d. Afonso VI. 12 de agosto de 1665. Idem, cx. 18, doc. 2103; Câmara de Salvador. Carta ao rei d. Afonso VI. 9 de agosto de 1666. Idem, cx. 19, doc. 2151; Conselho Ultramarino. Consulta ao rei d. Afonso VI. 26 de setembro de 1663. Idem, cód. 16, fl. 87v; DH, vol. 89, p. 223-4.

${ }^{81}$ Cf., por exemplo, CS, vol. II, p. 119.

${ }^{82}$ ALBUQUERQUE, Maria Isabel de (ed.). Liberdade e limitação dos engenhos d'açúcar. PRIMEIRO CONGRESSO DE HISTÓRIA DA BAHIA. Anais. Salvador, 1950, vol. II, p. 493-4.
} 
de Vossa Majestade e consultou aos principais homens da nobreza e governo daquela cidade, fidalgos, cidadãos, cavaleiros, senhores de engenho, lavradores de cana e mercadores". ${ }^{83}$ Tais enumerações são interessantes por dois motivos. Em primeiro lugar, porque aparecem aqui, primeiro, divisões de ordem e, depois, de classe, justamente num momento de consolidação da nobreza como conceito operacional da elite baiana.

Em segundo lugar, ambas as formas de classificação são constituintes das identidades individuais, como se vê, por exemplo, nas assinaturas de "Belchior Barreto, cidadão desta cidade, lavrador", "Capitão Francisco de Araújo de Brito, cavaleiro da ordem de Cristo, cidadão desta cidade, lavrador de canas", "Francisco de Negreiros Soeiro, cavaleiro do hábito de Avis, juiz ordinário que fui nesta cidade e vereador muitas vezes, lavrador de cana há mais de 45 anos" e "Diogo de Aragão, senhor de dois engenhos e fidalgo da casa de Vossa Majestade", ${ }^{84}$ dentre outros. É de se notar, porém, que nenhum deles define seu estatuto como parte da nobreza baiana, recorrendo antes à participação política como legitimadora de um estatuto superior e, quando podem, enfatizam as honrarias concedidas pelo centro monárquico. Se participar do governo de uma cidade "notável" como Salvador era um fator de distinção social, as honrarias concedidas pelo centro monárquico eram ainda mais, o que explica as centenas de pedidos de mercê desse grupo no século XVII. ${ }^{85}$

Se não simultaneamente, os mesmos indivíduos podiam aparecer num momento como parte da governança ou nobreza e, em outros, como senhores de engenho ou mesmo homens de negócio. Diogo de Aragão Pereira aparece, por exemplo, como senhor de engenho e homem da governança, assim como seu filho Pedro, alternadamente senhor de engenho e membro da nobreza. ${ }^{86}$ Tal dualidade não estava restrita, em verdade, aos senhores de engenho, aparecendo mesmo no caso dos homens de negócio, como Pedro Marinho Soutomaior, que serviu como vereador em 1656, apareceu como representante dos negociantes no ano seguinte e foi novamente vereador em 1661 e 1666, além de uma referência como cidadão em 1663. ${ }^{87}$

Já a Câmara podia usar as duas definições ao mesmo tempo, mesmo porque era a situação econômica a relevante para os propósitos de cobrança

\footnotetext{
${ }^{83}$ DH, vol. 66, p. 218-9 e 263-4; cf. também Conselho Ultramarino. Consulta ao rei d. Afonso VI. 6 de abril de 1663. AHU, cód. 16, fl. 71v.

${ }^{84}$ ALBUQUERQUE, Maria Isabel de, art. cit., p. 497-8.

${ }^{85}$ KRAUSE, Thiago Nascimento, op. cit., p. 93-167.

${ }^{86}$ AC, vol. II, p. 72-4 e 167-8; vol. III, p. 353-5; vol. V, p. 204-7 e 290.

${ }^{87}$ AC, vol. III, p. 353-5 e vol. IV, p. 163-6.
} 
de donativos, por exemplo. Em um exemplo precoce, assentou-se na Câmara em 28 de junho de 1641 que era preciso enviar um procurador para Lisboa para entrar em contato com o novo monarca e, para isso, necessitava-se de dinheiro. Determinaram, assim, "que o menos que havia de juntar entre os nobres desta cidade eram dois mil cruzados; para este efeito, se determinou se escrevessem cartas a todos os que eram e aos senhores de engenho e lavradores ricos para ajudarem cada um com o que lhes parecesse". ${ }^{88}$

Assim, "a metamorfose da açucarocracia" deve ser entendida como a transformação de uma situação estamental vaga ("homens da governança" e suas variações) para outra mais prestigiosa e honrada ("nobreza"), característica das principais municipalidades lusitanas. Ao mesmo tempo, a elite baiana continuava a agir como classe em momentos de interesse, realizando petições em nome dos senhores de engenho e lavradores e participando das decisões sobre o preço do açúcar, por exemplo. ${ }^{89}$ Tal combinação é possível e mesmo necessária porque, em última instância, o objetivo da atividade econômica não era simplesmente a obtenção de lucros, mas, sim, a manutenção do status social familiar e, até, quem sabe, a constituição de laços para fortalecer uma comunidade - a nobreza baiana. ${ }^{90}$ É nesse sentido, portanto, que deve ser compreendida a afirmação do supracitado papel, assinado em 1662 por 108 "pessoas principais", de que "o açúcar é a cabeça deste corpo místico que é o Brasil"."1

Classe e estamento são, em conjunto, dois conceitos fundamentais para a análise da América do século XVII, pois esta era, e creio que ainda mais que na Europa, "uma sociedade estamental tendencialmente classista, um mundo ordenado teoricamente pelo sangue e nascimento; distribuído em grupos em realidade graças ao dinheiro e às relações pessoais e familiares. Neste sentido, a nobreza é antes de tudo um ideal, um modo de vida, uma aspiração".92 Contudo, enquanto as categorias econômicas se mantiveram estáveis (com a exceção do aumento da proeminência dos homens de negócio), as categorias de honra e prestígio sofreram uma metamorfose decisiva - mesmo

\footnotetext{
${ }^{88}$ AC, vol. II, p. 28-30; cf. também p. 72-4, 183-5, 266-7 e 349; vol. III, p. 266-7, 311-4 e 353-5, dentre muitos outros exemplos.

${ }^{89}$ AC, vol. VI, p. 91-2, 185-6, 356-8 e 371-2.

${ }^{90}$ Cf. VAN YOUNG, Eric. Social networks: A final comment. In: BÖTTCHER, Nikolaus; HAUSBERGER, Bernd e IBARRA, Antonio (coords.). Redes y negocios globales en el mundo ibérico, siglos XVI-XVIII. Madri/Frankfurt: Iberoamericana/Vervuert, 2011, p. 300-5.

${ }^{91}$ ALBUQUERQUE, Maria Isabel de, art. cit., p. 494.

92 SORIA MESA, Enrique. La nobleza en la España moderna: cambio y continuidad. Madri: Marcial Pons, 2007, p. 319, tradução minha; cf. também p. 38-9 e 213-5.
} 
rev. hist. (São Paulo), n. 170, p. 201-232, jan.-jun., 2014 http://dx.doi.org/10.11606/issn.2316-9141.v0i170p201-232
Thiago Nascimento Krause

De homens da governança à primeira nobreza: vocabulário social e transformações estamentais na Bahia seiscentista

porque, numa sociedade gerada a partir da matriz do Antigo Regime ibérico, era a linguagem de ordens a mais importante, ao menos no campo simbólico.

\section{Nobreza e povo}

Se, como vimos, a nobreza baiana construiu-se de forma relacional, essa relação não se deu apenas com a Coroa e sua administração periférica. Deuse também, sem dúvida, com a população mais ampla. Por mais que o poder político fosse dominado por um grupo pequeno, ele era exercido em nome de um "povo" abstrato que se fazia presente em muitas reuniões da municipalidade. Por vezes, especialmente nas primeiras décadas abarcadas por este estudo, "povo" significa a sociedade política como um todo, incluindo tanto a elite quanto alguns grupos subalternos considerados merecedores de participação, mesmo que minoritária, no governo da República. Na maioria dos momentos, porém, "povo" representa apenas esses setores abaixo da elite, geralmente associados aos ofícios mecânicos, mas não identificados explicitamente. Uma definição mais precisa seria de grande valia, mas é dificultada pelas limitações documentais, inclusive devido à fragilidade das corporações de artesãos em Salvador. Em certa medida, é a própria indeterminação do conceito que lhe dava força retórica, pois permitia àqueles que falavam em nome do "povo" assumir a autoridade de porta-voz de toda a sociedade ${ }^{93}$ - liderados, é claro, pela elite.

Um dos únicos momentos em que os camaristas definem quem seria o povo, mesmo que de forma pejorativa, é em uma carta enviada em 28 de janeiro de 1668, criticando as despesas injustificadas dos vereadores do ano anterior:

(...) chamaram alguma gente de pouca condição deste povo, criados dos moradores e oficiais mecânicos, e para fazerem numero de 20 pessoas que nele assinaram fizeram também assinar pelos serventes desta câmara e havendo muita nobreza nesta cidade, muitos que foram juízes e vereadores nela não se acha nele assinado mais que Antônio de Souza de Andrade. ${ }^{94}$

Como afirmou Stuart Schwartz, “a vasta maioria da população era considerada por essa elite e pelo regime colonial como desmerecedora do seu status enquanto povo da colônia". ${ }^{95}$ É certo, porém, que escravos, criados, mu-

\footnotetext{
${ }^{95}$ Como notou CHAMBOULEYRON, Rafael Ivan. "Duplicados clamores": queixas e rebeliões na Amazônia colonial (século XVII). Projeto História. São Paulo, n. 33, 2006, p. 172-3.

${ }^{94}$ Câmara de Salvador. Carta ao rei d. Afonso VI. 28 de janeiro de 1668. AHU, Bahia, LF, cx. 20, doc. 2238.

95 SCHWARTZ, Stuart. "Gente da terra braziliense da nasção": Pensando o Brasil. A construção de um povo. In: MOTA, Carlos Guilherme (org.). Viagem incompleta: a experiência brasileira (1500-2000),
} 
rev. hist. (São Paulo), n. 170, p. 201-232, jan.-jun., 2014 http://dx.doi.org/10.11606/issn.2316-9141.v0i170p201-232
Thiago Nascimento Krause

De homens da governança à primeira nobreza: vocabulário social e transformações estamentais na Bahia seiscentista

lheres e crianças, como subordinados aos patres familias, não tinham lugar no corpo político. Tanto os juízes do povo quanto os mesteres e o escrivão eram artesãos brancos e relativamente bem-sucedidos, e era esse grupo que eles representavam, ${ }^{96}$ e não a massa pobre e parda que cresceu em Salvador ao longo do século. Eram donos de propriedades e escravos, casados e com filhos.

É de se supor que o apoio desse "povo" (definido de forma profundamente excludente) fosse importante para a legitimação da açucarocracia como "nobreza" responsável pelo governo político da República. Por isso, desde os primeiros registros, é possível encontrar referências a decisões tomadas conjuntamente pelos "homens da governança e povo". ${ }^{97}$ Como dá a entender uma ata da eleição de um procurador em 1644 da qual participam “a nobreza do povo e mais misteres dele" e de um juiz e um vereador em 1666, para a qual foi chamada "a nobreza deste povo", ou ainda o debate sobre a necessidade de se enviar procurador a Lisboa, quando novamente se convocou "a nobreza deste povo", a elite se define a partir de sua posição superior dentro do povo. ${ }^{98}$ Como a nobreza baiana fazia, na prática, parte de um estrato superior do terceiro Estado (assim como todas as elites locais portuguesas), ${ }^{99}$ apesar da divisão tripartida dos três Estados da República que se repetiu algumas vezes ao longo do século XVII, tal situação fazia sentido, pois a construção dessa nobreza era profundamente local e costumeira. No mínimo, a anuência do "povo" era essencial para assegurar algum grau de cumprimento das posturas camarárias e para coletar efetivamente as contribuições excepcionais diretas frequentemente lançadas pela Câmara. Daí a recorrência da expressão "nobreza e povo", que aparece 56 vezes na documentação da Câmara entre 1642 e 1700, geralmente na discussão de temas politicamente relevantes, como a fiscalidade. Os artesãos de Salvador são, portanto, o terceiro - e mais obscuro - polo relacional na formação da nobreza baiana.

vol. I: Formação - Histórias. São Paulo: Senac, 2000, p. 116.

${ }^{96}$ FLORY, Rae. Bahian society in the mid-colonial period: the sugar planters, tobacco growers, merchants, and artisans of Salvador and the Reconcavo, 1680-1725. Tese de doutorado em História, Universidade do Texas, 1978, p. 281-343; FLEXOR, Maria Helena Ochi. Ofícios, manufaturas e comércio. In: SXMRECSÁNYI, Tamás (org.). História econômica do período colonial. $2^{\mathrm{a}}$ ed. São Paulo: Hucitec/Edusp/ Imprensa Oficial, 2002, p. 173-94. O mesmo pode ser dito para o Porto: SILVA, Francisco Ribeiro da, op. cit., vol. I, p. 234 e 309-15, e provavelmente para as principais cidades portuguesas. ${ }_{97}$ AC, vol. I, p. 76-7.

${ }^{98}$ AC, vol. II, p. 237-8 e vol. IV, p. 246 e 407-9; para passagens similares, cf. vol. I, p. 187-8; vol. II, p. 265-6 e 321-6; vol. III, p. 88-95, 98-100 e 127-8; vol. IV, p. 352-3, 356 e 402-3; e Câmara de Salvador. Carta ao rei d. Felipe III de Portugal. 16 de maio de 1626. AHU, Bahia, LF, cx. 3, doc. 423. 99 MAGALHÃES, Joaquim Romero. O Algarve econômico, 1600-1773. $2^{\mathrm{a}}$ ed. Lisboa: Estampa, 1993, p. 348. 
rev. hist. (São Paulo), n. 170, p. 201-232, jan.-jun., 2014 http://dx.doi.org/10.11606/issn.2316-9141.v0i170p201-232
Thiago Nascimento Krause

De homens da governança à primeira nobreza: vocabulário social e transformações estamentais na Bahia seiscentista

\section{Conclusão}

A nobreza na Bahia na segunda metade do século XVII era reconhecida como tal pela sociedade, pela Coroa e pela administração periférica, situação que trazia efeitos práticos. Se seu status social não era o mesmo das mais fidalgas câmaras do reino, como Porto, ${ }^{100}$ Coimbra ${ }^{101}$ e Évora, ${ }^{102}$ ao menos as elites baianas e pernambucanas se comparavam favoravelmente ao grupo dominante de muitas outras áreas do reino, como no Algarve, em termos de riqueza e da nobilitação concedida pela Coroa, na forma de hábitos e foros de fidalgo - e estas nem por isso deixaram de se qualificar como nobreza. ${ }^{103}$

A própria nobreza, como ordem social, é uma construção ideológica, já que está baseada na honra e no prestígio, e esses são atributos que estão no olho do observador e não necessariamente inscritos na realidade material. Era o reconhecimento público da condição de nobre que permitia a um indivíduo - ou grupo - fazer jus aos privilégios definidos pelo direito e pelo costume. No Brasil, como em Portugal, "as fronteiras locais da nobreza camarária dependiam, assim, das tradições de cada terra e das relações de força no terreno, de arranjos locais, em suma, e não do estatuto geral delimitado pela legislação".104 $\mathrm{O}$ caráter ideológico da constituição das nobrezas não implica, porém, sua irrelevância, pois ele gerava efeitos reais de grande significado, especialmente o controle político da localidade por parte de uma elite socialmente distinta que, através dessa estratégia discursiva, reforçava seu poder, influência e legitimidade.

Cabe enfatizar, porém, que o grupo social reinol com o qual devem se estabelecer comparações não era a aristocracia de Corte, mas as numerosas elites locais a pontilhar o território português - e europeu, em verdade. Outra armadilha a ser evitada é a utilização do termo "nobreza da terra" como um belo sinônimo para as elites brasílicas em qualquer situação. Sem dúvida, houve nobres em todas as regiões da América portuguesa, algo natural quando consideramos a porosidade da nobreza lusitana. Creio, porém, que a

\footnotetext{
${ }^{100}$ SILVA, Francisco Ribeiro da, op. cit., vol. I, p. 281-309.

${ }^{101}$ SOARES, Sérgio Cunha. O município de Coimbra da Restauração ao pombalismo. Poder e poderosos na Idade Moderna, vol. II. Coimbra: Centro de História da Sociedade e da Cultura, 2002, p. 57-105. ${ }^{102}$ PARDAL, Rute. As elites de Évora ao tempo da dominação filipina. Estratégias de controlo do poder local (1580-1640). Lisboa: Colibri, 2007, p. 110-1.

${ }^{103}$ MAGALHÃES, Joaquim Romero, op. cit., p. 323-62.

${ }^{104}$ MONTEIRO, Nuno Gonçalo. Os concelhos e as comunidades. In: MATTOSO, José (dir.) e HESPANHA, António Manoel (org.), op. cit., p. 291.
} 
utilização do termo "nobreza" deve ser precedida de uma série de cuidados, pois seu emprego como substantivo coletivo pressupõe aspectos de coesão e unidade que não devem ser vistos como dados, mas como processos que resultam de uma evolução histórica a ser traçada em cada região, atentando especialmente para os aspectos sociais e políticos que moldaram a evolução do vocabulário social. Fazer o contrário é ignorar as percepções coevas fundamentais para a construção das hierarquias sociais no mundo moderno.

\section{Referências bibliográficas}

\section{Fontes publicadas}

Traslado dos privilégios que sua majestade concedeu aos cidadãos da Bahia de Todos os Santos. In: Revista do Instituto Histórico e Geográfico Brasileiro, tomo VIII. $2^{\mathrm{a}}$ ed., 1867, p. 512-26.

ALBUQUERQUE, Maria Isabel de (ed.). Liberdade e limitação dos engenhos d'açúcar. PRIMEIRO CONGRESSO DE HISTÓRIA DA BAHIA. Anais. Salvador, 1950, vol. II, p. 491-9.

Documentos históricos da Biblioteca Nacional do Rio de Janeiro. Rio de Janeiro: Biblioteca Nacional, 1928-2011, 112 volumes (DH).

Documentos históricos do Arquivo Municipal. Atas da Câmara. Salvador: Prefeitura Municipal, 11 vols. (1625-1775), 1949-2011. (AC)

Documentos históricos do Arquivo Municipal. Cartas do Senado, 6 vols. (16481730). Salvador: Prefeitura Municipal, 1951-84 (CS).

ESTEVES, Neuza Rodrigues (ed.). Catálogo dos irmãos da Santa Casa de Misericórdia da Bahia: século XVII. Salvador: Santa Casa de Misericórdia da Bahia, 1977.

FONSECA, Luiza da. Bacharéis brasileiros: elementos biográficos. IV CONGRESSO DE HISTÓRIA NACIONAL. Anais. Rio de Janeiro: Imprensa Nacional, 1951, vol. IX, p. 109-405.

GANDAVO, Pero de Magalhães. Tratado da terra do Brasil \& História da província Santa Cruz a que vulgarmente chamamos Brasil, 1576. Recife: Massangana, 1995.

Livro das denunciações que se fizerão na visitação do Santo Offício á cidade do Salvador da Bahia de Todos os Santos do Estado do Brasil, no anno de 1618. Inquiridor e visitador o licenciado Marcos Teixeira. Anais da Biblioteca Nacional. Rio de Janeiro: Biblioteca Nacional, 1936, vol. 49, p. 75-198.

PISSURLENCAR, Panduronga. Assentos do Conselho de Estado. Bastorá/Goa: Tipografia Rangel, 1956-7, vol. 4 (1659-95) e vol. 5 (1696-1750).

PITTA, Sebastião da Rocha. Breve compêndio e narração do fúnebre espetáculo que na insigne cidade da Bahia, cabeça da América portuguesa, se viu na morte de el-rey d. Pedro II, de gloriosa memória, senhor nosso. Lisboa: Oficina de Valentim da Costa Deslandes, 1709.

PITTA, Sebastião da Rocha. História da América portuguesa. Lisboa: Oficina de Joseph Antônio da Silva, 1730.

SILVA, José Justino de Andrade e. Colleç̧ão chronológica da legislação portugueza. Lisboa: Imprensa de J. J. A. Silva, 1854-9, 11 volumes (CCLP). 
rev. hist. (São Paulo), n. 170, p. 201-232, jan.-jun., 2014 http://dx.doi.org/10.11606/issn.2316-9141.v0i170p201-232
Thiago Nascimento Krause

De homens da governança à primeira nobreza: vocabulário social e transformações estamentais na Bahia seiscentista

SIQUEIRA, Sônia (ed.). Confissões da Bahia (1618-1620). 2a ed. João Pessoa: Ideia, 2011. SOUSA, Gabriel Soares de. Tratado descritivo do Brasil em 1587. São Paulo: Hedra, 2010. TOPA, Francisco. Edição crítica da obra poética de Gregório de Matos, vol. II. Tese de doutorado, Faculdade de Letras, Universidade do Porto, 1999.

VAINFAS, Ronaldo (org.). Confissões da Bahia. $2^{\text {a }}$ ed. São Paulo: Companhia das Letras, 1997.

\section{Bibliografia}

BICALHO, Maria Fernanda. A cidade e o império: o Rio de Janeiro no século XVIII. Rio de Janeiro: Civilização Brasileira, 2003.

BÜSCHGES, Christian. Introducción In: Idem e SCHRÖTER, Bernd (eds.). Benméritos, aristócratas y empresários: identidades y estructuras sociales de las capas altas urbanas en América hispânica. Madri/Frankfurt: Iberoamericana/Vervuert, 1999, p. 9-16.

e SCHRÖTER, Bernd. Las capas altas urbanas en la América hispânica colonial. In: Idem (eds.). Benméritos, aristócratas y empresários: identidades y estructuras sociales de las capas altas urbanas en América hispânica. Madri/Frankfurt: Iberoamericana/Vervuert, 1999, p. 299-315.

CARDIM, Pedro. Entre o centro e as periferias. A assembleia de Cortes e a dinâmica política da Época Moderna In: CUNHA, Mafalda Soares da e FONSECA, Teresa (orgs.). Os municípios no Portugal moderno: dos forais manuelinos às reformas liberais. Lisboa: Colibri, 2005, p. 167-242.

The representatives of Asian and American cities at the Cortes of Portugal. In: Idem; HERZOG, Tamar; RUIZ IBÁNEZ, José Javier e SABATINI, Gaetano (eds.). Polycentric monarchies: How did early modern Spain and Portugal achieve and maintain a global hegemony? Eastbourne: Sussex Academic Press, 2012, p. 43-53.

CARSTEN, Francis Ludwig. A nobreza de Brandeburgo e da Prússia dos séculos XVI a XVIII: ordem, casta ou classe social. In: MOUSNIER, Roland (org.). Problemas de estratificação social. Tradução. Lisboa: Cosmos, 1988, p. 199-220.

CHAMBOULEYRON, Rafael Ivan. "Duplicados clamores": queixas e rebeliões na Amazônia colonial (século XVII). Projeto História, São Paulo, n. 33, 2006, p. 159-78.

COLLINS, James B. Classes, estates, and order in early modern Brittany. Cambridge: Cambridge University Press, 1994. http://dx.doi.org/10.1017/CBO9780511562587.

FLEXOR, Maria Helena Ochi. Ofícios, manufaturas e comércio. In: SXMRECSÁNYI, Tamás (org.). História econômica do período colonial. $2^{\mathrm{a}}$ ed. São Paulo: Hucitec/Edusp/ Imprensa Oficial, 2002, p. 173-94.

FLORY, Rae. Bahian society in the mid-colonial period: the sugar planters, tobacco growers, merchants, and artisans of Salvador and the Reconcavo, 1680-1725. Tese de doutorado em História, Universidade do Texas, 1978.

e SMITH, David Grant. Bahian merchants and planters in the seventeenth and early eighteenth centuries. The Hispanic American Historical Review, Durham, vol. 58, n. 4, novembro de 1978, p. 571-94. http://dx.doi.org/10.2307/2513341.

FRAGOSO, João. À espera das frotas: micro-história tapuia e a nobreza principal da terra (Rio de Janeiro, c. 1600 - c. 1750). Tese de titular em Teoria da História, Departamento de História, Universidade Federal do Rio de Janeiro, 2005. 
rev. hist. (São Paulo), n. 170, p. 201-232, jan.-jun., 2014 http://dx.doi.org/10.11606/issn.2316-9141.v0i170p201-232
Thiago Nascimento Krause

De homens da governança à primeira nobreza: vocabulário social e transformações estamentais na Bahia seiscentista

GREGÓRIO, Rute Dias. Configurações de uma pequena nobreza e seu patrimônio, Açores, séculos $X V$ e XVI. 2010. Disponível em: https://repositorio.uac.pt/handle/10400.3/1084. Acesso em: 19/03/2013.

RODRIGUES, José Damião. Sociedade e administração nos Açores (séculos XV-XVIII): O caso de Santa Maria. Arquipélago-História, Ponta Delgada, $2^{\mathrm{a}}$ série, vol. I, no 2: Estudos insulares, 1995, p. 33-63.

KICZA, John. Formación, identidade y estabilidade dentro de la elite colonial mexicana en los siglos XVI y XVII. In: BÜSCHGES, Christian e SCHRÖTER, Bernd (eds.). Benméritos, aristócratas y empresários: identidades y estructuras sociales de las capas altas urbanas en América hispânica. Madri/Frankfurt: Iberoamericana/Vervuert, 1999, p. 17-34.

KRAUSE, Thiago Nascimento. Em busca da honra: a remuneração dos serviços da guerra holandesa e os hábitos das ordens militares (Bahia e Pernambuco, 1641-83). São Paulo: Annablume, 2012.

LEONHARD, Jörn e WIELAND, Christian. Noble identities from the sixteenth to the twentieth century. In: Idem (eds.). What makes the nobility noble? Göttingen: Vandenhoeck \& Ruprecht, 2011, p. 7-32.

MAGALHÃES, Joaquim Romero. O Algarve econômico, 1600-1773. 2 ${ }^{\mathrm{a}}$ ed. Lisboa: Estampa, 1993.

Os nobres da governança das terras. In: MONTEIRO, Nuno; CARDIM, Pedro e CUNHA, Mafalda Soares da (coords.). Optima Pars: elites ibero-americanas do Antigo Regime. Lisboa: Imprensa de Ciências Sociais, 2005, p. 65-71.

MELLO, Evaldo Cabral de. Rubro veio: o imaginário da Restauração pernambucana. $3^{\mathrm{a}}$ ed. rev. São Paulo: Alameda, 2008.

A fronda dos mazombos: nobres contra mascates, Pernambuco, 1666-1715. $2^{\mathrm{a}}$ ed. rev. São Paulo: 34, 2003.

MONTEIRO, Nuno Gonçalo. O crepúsculo dos grandes: Casa e patrimônio da aristocracia em Portugal (1750-1834). Lisboa: Imprensa Nacional - Casa da Moeda, 1998.

Os concelhos e as comunidades. In: MATTOSO, José (dir.) e HESPANHA, António Manuel. História de Portugal, vol. IV: O Antigo Regime (1620-1807). $2^{\text {a }}$ ed. Lisboa: Estampa, 1998, p. 269-95.

Poder senhorial, estatuto nobiliárquico e aristocracia. In: MATTOSO, José (dir.) e HESPANHA, António Manuel. História de Portugal, vol. IV: O Antigo Regime (1620-1807). 2a ed. Lisboa: Estampa, 1998, p. 297-338.

PARDAL, Rute. As elites de Évora ao tempo da dominação filipina. Estratégias de controlo do poder local (1580-1640). Lisboa: Colibri, 2007.

PERES, Fernando da Rocha. Gregório de Mattos: o poeta devorador. Rio de Janeiro: Manati, 2004.

RICUPERO, Rodrigo. A formação da elite colonial. Brasil, c. 1530 - c. 1630. São Paulo: Alameda, 2008.

SCHWARTZ, Stuart. Burocracia e sociedade no Brasil colonial: a Suprema Corte da Bahia e seus juízes (1609-1751). Tradução. São Paulo: Perspectiva, 1979.

. Segredos internos: engenhos e escravos na sociedade colonial, 1550-1835. Tradução. São Paulo: Companhia das Letras, 1988. 
rev. hist. (São Paulo), n. 170, p. 201-232, jan.-jun., 2014 http://dx.doi.org/10.11606/issn.2316-9141.v0i170p201-232
Thiago Nascimento Krause

De homens da governança à primeira nobreza: vocabulário social e transformações estamentais na Bahia seiscentista

"Gente da terra braziliense da nasção": Pensando o Brasil. A construção de um povo. In: MOTA, Carlos Guilherme (org.). Viagem incompleta: a experiência brasileira (1500-2000), vol. I: Formação - Histórias. São Paulo: Senac, 2000, p. 103-25.

. The king's processions: Municipal and royal authority and the hierarchies of power in colonial Salvador. In: ROCKEY, Liam Matthew (org.). Portuguese colonial cities in the early modern world. Aldershot: Ashgate, 2008, p. 177-204.

$\mathcal{E}$ PÉCORA, Alcir (org.). As excelências do governador: o panegírico fúnebre a d. Afonso Furtado, de Juan Lopes Sierra (Bahia, 1676). Tradução. São Paulo: Companhia das Letras, 2002.

SCOTT, Hamish e STORRS, Christopher. The consolidation of noble power in Europe, c. 1600-1800. In: SCOTT, Hamish (ed.). The European nobilities in the seventeenth and eighteenth-centuries, vol. 1: Western and southwestern Europe. $2^{\mathrm{a}}$ ed. rev. e amplilada. Nova York: Palgrave Macmillan, 2007, p. 1-60.

SILVA, Francisco Ribeiro da. O Porto e o seu termo (1580-1640): os homens, as instituições e o poder. Porto: Arquivo Histórico/Câmara Municipal, 1988.

SOARES, Sérgio Cunha. O município de Coimbra da Restauração ao pombalismo. Poder e poderosos na Idade Moderna, vol. II. Coimbra: Centro de História da Sociedade e da Cultura, 2002.

SORIA MESA, Enrique. La nobleza en la España moderna: cambio y continuidad. Madri: Marcial Pons, 2007.

SOUZA, Laura de Mello e. O sol e a sombra: política e administração na América portuguesa do século XVIII. São Paulo: Companhia das Letras, 2006.

THOMPSON, Irving. La monarquía de España: La invención de um concepto. In: ÁLVAREZ, Francisco Guillamón; RODRÍGUEZ, Júlio Muñoz e ARCE, Domingo Centenero (eds.). Entre Clío y Cassandra: Poder y sociedad en la monarquía hispánica durante la Edad Moderna. Murcia: Universidade de Murcia, 2005, p. 31-58.

VAN YOUNG, Eric. Social networks: A final comment. In: BÖTTCHER, Nikolaus; HAUSBERGER, Bernd e IBARRA, Antonio (coords.). Redes y negocios globales en el mundo ibérico, siglos XVI-XVIII. Madri/Frankfurt: Iberoamericana/ Vervuert, 2011, p. 289-310.

WEBER, Max. Classe, estamento, partido. In: Idem. Ensaios de Sociologia. Tradução. $5^{\mathrm{a}}$ ed. Rio de Janeiro: LTC, 1982, p. 211-28. 